\title{
INFLUENCE OF SOLUTION CONCENTRATION AND EQUILIBRIUM TIME ON PHOSPHORUS SORPTION IN CALCAREOUS AND NON-CALCAREOUS SOILS
}

\author{
J.C. Joardar*, S. Sikder and S.B. Hasib \\ Soil, Water and Environment Discipline, Khulna University, Khulna-9208, Bangladesh
}

\begin{abstract}
Low availability of phosphorus $(\mathrm{P})$ due to $\mathrm{P}$ sorption onto soil is one of the major hindrances that greatly affect crop production. So, the understanding of P-soil interactions plays a vital role for increasing agronomic efficiency as well as proper $\mathrm{P}$ management. For optimal crop production, annual $\mathrm{P}$ application rates should be in equilibrium with the rate of $P$ sorption by soil to ensure the presence of sufficient $P$ in soil. So, it is important to identify the rate of $P$ sorption with time. The focus of this study was to determine and compare the influence of solution $P$ concentrations and equilibrium time on $\mathrm{P}$ sorption in calcareous and noncalcareous soils. In the experiment, $0,2.5,5,10,20$ and $50 \mu \mathrm{g} \mathrm{P} \mathrm{ml}^{-1}$ solutions were taken and the sorption rate was investigated at 6, 12, 24 and 48 hour time periods. The results indicate that the $P$ retention onto soil significantly increased with increasing concentration of solution $P$. Equilibrium time also influenced $P$ sorption. The maximum $P$ sorption was found after 24 hours. After 48 hours, some desorption of fixed $\mathrm{P}$ was observed that reflects the reversibility of sorbed $P$ with time. The higher $P$ sorption was found in calcareous soil than in noncalcareous soil irrespective of equilibrium time and solution $\mathrm{P}$ concentration.
\end{abstract}

Keywords: Calcareous soil, Phosphorus, Sorption

\section{INTRODUCTION}

Proper management and efficient use of plant nutrients, which ensure the nutrient availability to plants, can be considered as the prerequisite for maintaining soil fertility and crop productivity (Cordell et al., 2009; Worstall, 2013). Phosphorus (P), next to $\mathrm{N}$ is the most important macronutrient. Adequate amount of $\mathrm{P}$ is essential from the very early stage of plant growth especially for the promotion of root formation and it plays a key role for a number of physiological functions including energy generation and transfer, photosynthesis, energy storage, respiration, cell enlargement, enzyme activation, membrane synthesis, nitrogen fixation and so on (Grant et al., 2001; Withers and Jarvie, 2008; Mullins, 2009).

Understanding soil $\mathrm{P}$ behavior is a fundamental and major task to assume the biogeochemical cycle of highly reactive $\mathrm{P}$ in soil and to ensure proper plant nutrition

\footnotetext{
" Corresponding author: jcjoardar@yahoo.com
} 
because soil contains very low amount of $\mathrm{P}$ (ranging from 0.01 to $0.1 \%$ ) and due to many reasons the soil $\mathrm{P}$ remains unavailable to plants. Adsorption or fixation mechanism of $\mathrm{P}$ onto soil over time results in the conversion of readily available to stable forms is one of the major factors that affects $\mathrm{P}$ availability in soils (Chen and Ma, 2001; Hopkins and Ellsworth, 2005). Phosphorus chemically binds with Fe and $\mathrm{Al}$ to form insoluble $\mathrm{Fe}$ and $\mathrm{Al}$ phosphates in acid soils and with $\mathrm{Ca}$ to form insoluble Ca phosphates in alkaline soils (Brady and Weil, 2002). The calcareous soils contain significant quantities of free $\mathrm{CaCO}_{3}$ (1 to 40\%) (Thompson, 2007). On the other hand, non-calcareous soils containing less than $1 \% \mathrm{CaCO}_{3}$ also exhibit $\mathrm{P}$ adsorption and it is the main retention mechanism for $P$ in this type of soil (Thompson, 2007). The $\mathrm{P}$ adsorption processes in both calcareous and non-calcareous soils are highly dependent on solution concentration and equilibrium time. Phosphorus retention by both the soils increases with the amount of added P. With time, the applied phosphate tightly bind on adsorption sites of $\mathrm{CaCO}_{3}$ and the extractability of applied $\mathrm{P}$ in soils decreases with increasing time (Rajput et al., 2014).

Globally, poor $\mathrm{P}$ availability in calcareous soil and consequent P-deficiency represents a major constraint to crop production (Ahemad et al., 2009). In Bangladesh, available $\mathrm{P}$ status is poor and availability of $\mathrm{P}$ to the crops is a problem mainly in calcareous soils of Ganges floodplain (Moslehuddin et al., 1997). When $P$ is added to soils as fertilizer, a series of reactions takes place especially $\mathrm{P}$ adsorption. It is estimated that only $10-15 \% \mathrm{P}$ are taken up by plant in the year of fertilizer application within 2 to 4 weeks more than $90 \%$ of inorganic $\mathrm{P}$ is fixed by soil (Sharpley and Beegle, 2001; Brady and Weil, 2002). More study on P management regarding $\mathrm{P}$ adsorption characteristics in soils is necessary to conserve and maintain this non-renewable resource. Considering proper understanding of $\mathrm{P}$ adsorption or retention in these soils, the present experiment aimed at evaluating the effects of solution $\mathrm{P}$ concentration and equilibrium time on $\mathrm{P}$ sorption in both calcareous and non-calcareous soils.

\section{MATERIALS AND METHODS}

The experiment was conducted in the laboratory of Soil, Water and Environment discipline, Khulna University, Bangladesh.

\section{General information about soil sampling sites}

Soil samples were collected from the agricultural field at Gutudia of Dumuriaupazilla, Khulna. Calcareous soil belongs to Dumuria soil series and noncalcareous soil belongs to Barisal soil series. The land type is medium high land for both soils. The lands are mainly used for rice cultivation.

Collection and preparation of soil samples

Both soils were collected at a depth of $0-15 \mathrm{~cm}$ on the basis of composite sampling method. Field identification method was used to identify calcareous and non- 
calcareous soils. The emergence of effervescence or fizzing after placing few drops of dilute hydrochloric acid $(10 \% \mathrm{HCl})$ indicated the presence of free $\mathrm{CaCO}_{3}$ in soil. After that, the collected soil samples were air dried and the larger aggregates were broken gently by crushing with a wooden hammer and passed through a $0.5-\mathrm{mm}$ sieve and the samples were preserved in plastic bags for experiment and analysis.

\section{Soil analysis}

Particle size analysis of the soils was done by combination of sieving and hydrometer method as described by Gee and Bauder (1986). Textural classes were determined by Marshall's triangular co-ordinate system by the respective percentage of soil separates (Brady and Weil, 2002). Soil pH, EC and total $\mathrm{P}$ were determined by following the procedure (Huq and Alam, 2005).

\section{$P$ sorption studies}

Equilibration procedure

Both calcareous and non-calcareous soils were used for this experiment. Triplicate $1.0 \mathrm{~g}$ soil sample was weighed into a series of $50-\mathrm{ml}$ polyethylene centrifuge tubes. Twenty five (25) $\mathrm{ml}$ each of P solution, containing $0,2.5,5.0,10.0,20.0$ and $50.0 \mu \mathrm{g}$ $\mathrm{P} \mathrm{ml}^{-1}$, were added to the tubes. The $\mathrm{pH}$ of the soil suspensions was adjusted to 6.0 with $0.1 \mathrm{M} \mathrm{HCl}$ or $0.1 \mathrm{M} \mathrm{NaOH}$. The amount of $\mathrm{HCl}$ or $\mathrm{NaOH}$ added for adjusting $\mathrm{pH}$ was taken into account in calculating the total volume of the equilibrating solution. The reason for choosing $\mathrm{pH} 6.0$ in this experiment was that adsorption isotherms have been reported to be better defined at this $\mathrm{pH}$ than at other $\mathrm{pH}$ levels (Shuman, 1975). The tubes were shaken on a reciprocating shaker for two hours and were allowed to equilibrate at room temperature for $6,12,24$ and 48 hours. Immediately following the equilibration period, the suspensions were centrifuged and filtered. The filtrates were analyzed for P by spectrophotometry.

\section{Calculation of $P$ sorption}

Isotherms were computed in the usual way by subtracting the $\mathrm{P}$ remaining in solution from the original $\mathrm{P}$ and assuming the difference represented the adsorbed $\mathrm{P}$. The zero $\mathrm{P}$ solution was used as background $\mathrm{P}$ for the experiment and these values were subtracted from the others to correct for the $\mathrm{P}$ that was released from the untreated soil. The following form of the Langmuir adsorption isotherm was tested to calculate the adsorption coefficients (Joardar et al., 2005):

$\frac{\mathrm{C}}{\mathrm{X}}=\frac{1}{\mathrm{~kb}}+\frac{\mathrm{C}}{\mathrm{b}}$

Where,

$\mathrm{C}=$ Equilibrium concentration of $\mathrm{P}$ in solution $\left(\mu \mathrm{g} \mathrm{ml}^{-1}\right)$

$\mathrm{X}=$ Amount of $\mathrm{P}$ adsorbed $\left(\mu \mathrm{g} \mathrm{g}^{-1}\right)$

$\mathrm{b}=$ Adsorption maximum $\left(\mu \mathrm{g} \mathrm{g}^{-1}\right)$ 
$\mathrm{k}=$ Constant related to the bonding energy of $\mathrm{P}$ to the soil $\left(\mathrm{ml} \mu \mathrm{g}^{-1}\right)$

A plot of $\mathrm{C} / \mathrm{X}$ versus $\mathrm{C}$ was made for both soils. The values of adsorption maximum and bonding energy were calculated from slope $(1 / \mathrm{b})$ and intercept $(1 / \mathrm{kb})$ of the plot, respectively.

\section{Statistical analysis}

The results were expressed as the average of four replications. The data was subjected to ANOVA using computer built-in statistical software program Minitab16. Differences between means were statistically analyzed using Fisher method $(\mathrm{p}=0.05)$. Graphs were prepared by using computer built-in Microsoft Excel-2010 program.

\section{RESULTS AND DISCUSSION}

\section{Soil properties}

Some soil properties are presented in Table 1. The EC values were determined as $6.98 \mathrm{dSm}^{-1}$ and $8.42 \mathrm{dSm}^{-1}$ which can be categorized as moderately saline and saline for calcareous and non-calcareous soils, respectively (Karim et al., 1990). The pH value of calcareous soil sample was 7.45 and non-calcareous soil was 6.87 , which are slightly alkaline and neutral soil in nature (Soil survey manual, 1993). The total $\mathrm{P}$ status of the soils was low with regards to the range of soil nutrients. The soil textural class was determined by the respective percentage of soil separates (Soil Survey Staff, 1951) and the observed calcareous soil was clay type and non-calcareous soil was silty clay.

Table 1. Some properties of both calcareous and non-calcareous soils

\begin{tabular}{l|c|c|c|c|c|c|c}
\hline Soil type & $\begin{array}{c}\mathrm{EC} \\
\left(\mathrm{dSm}^{-1}\right)\end{array}$ & $\mathrm{pH}$ & $\begin{array}{c}\text { Total P } \\
(\%)\end{array}$ & $\begin{array}{c}\text { Sand } \\
(\%)\end{array}$ & $\begin{array}{c}\text { Silt } \\
(\%)\end{array}$ & $\begin{array}{c}\text { Clay } \\
(\%)\end{array}$ & $\begin{array}{c}\text { Textural } \\
\text { Class }\end{array}$ \\
\hline Calcareous & 6.98 & 7.45 & 0.072 & 12 & 35 & 53 & Clay \\
Non-calcareous & 8.24 & 6.87 & 0.068 & 8 & 41 & 51 & Silty Clay \\
\hline
\end{tabular}

\section{Sorption of $P$ at different solution concentrations}

The $\mathrm{P}$ sorption onto soil at different solution $\mathrm{P}$ concentrations at four specific equilibrium times and comparison between calcareous and non-calcareous soils are shown in Table 2 . The $\mathrm{P}$ sorption increased significantly with the increase of solution $\mathrm{P}$ concentration irrespective to time duration and soil type (calcareous and noncalcareous soil). In this experiment, the $50 \mu \mathrm{gml}^{-1} \mathrm{P}$ concentration showed the highest and $2.5 \mu \mathrm{gml}^{-1}$ showed the lowest adsorption in both soils. It was also reported that $\mathrm{P}$ sorption significantly increased with increasing $\mathrm{P}$ concentration in calcareous and non-calcareous soils (Zhou and Li, 2001; Jalali, 2007; Rajput et al., 2014). In the present study, sorption rate is higher in calcareous soil than non-calcareous soil in 
every case. The primary reason might be the presence of large amounts of free $\mathrm{CaCO}_{3}$ in calcareous soil which is very active for P sorption. Afsar et al. (2012a, b) also stated that at the same concentrations of $\mathrm{P}$ in solution, calcareous soils sorbed more $\mathrm{P}$ in their labile pool than that of non-calcareous soils. In addition to solution $\mathrm{P}$ concentration, sorption was significantly influenced by $\mathrm{pH}$ and soil texture. In this experiment, the observed $\mathrm{pH}$ of calcareous soil was quite high (7.45) and it was estimated that, above $\mathrm{pH} 7.0, \mathrm{Ca}^{+2}$ ions can precipitate with $\mathrm{P}$ as Ca-P mineral and cause scarcity of this nutrient (Bubba et al., 2003; Saleh et al., 2015). In case of texture, the observed calcareous soil was clay in nature. Numerous studies reported that clay content plays a vital role in P sorption (Kaloi et al., 2011). On the other hand, experimented non-calcareous soil was silty clay type and silt fraction also has a great influence on P sorption as mentioned by Awasthi and Pathak (1971); Yadav et al. (2017).

Table 2. P sorption by calcareous and non-calcareous soils

\begin{tabular}{ccccccc}
\hline $\begin{array}{c}\text { Solution } \\
\text { Concentration }\end{array}$ & $0 \mu g m l^{-1}$ & $2.5 \mu g m l^{-}$ & $5 \mu \mathrm{gml}^{-1}$ & $10 \mu \mathrm{gml}^{-1}$ & $20 \mu \mathrm{gml}^{-1}$ & $50 \mu \mathrm{gml}^{-1}$ \\
\hline Time (hours) & \multicolumn{7}{c}{ P adsorption, $\mathrm{X}\left(\mu \mathrm{gg}^{-1}\right)$} \\
\hline \multicolumn{7}{c}{ Calcareous soil } \\
\hline 6 & ${ }^{\mathrm{A}} 0.00^{\mathrm{e}}$ & ${ }^{\mathrm{B}} 58.00^{\mathrm{d}}$ & ${ }^{\mathrm{D}} 60.00^{\mathrm{d}}$ & ${ }^{\mathrm{C}} 76.76^{\mathrm{c}}$ & ${ }^{\mathrm{C}} 329.50^{\mathrm{b}}$ & ${ }^{\mathrm{D}} 631.9^{\mathrm{a}}$ \\
12 & ${ }^{\mathrm{A}} 0.00^{\mathrm{f}}$ & ${ }^{\mathrm{A}} 59.25^{\mathrm{e}}$ & ${ }^{\mathrm{C}} 65.50^{\mathrm{d}}$ & ${ }^{\mathrm{C}} 79.77^{\mathrm{c}}$ & ${ }^{\mathrm{B}} 341.25^{\mathrm{b}}$ & ${ }^{\mathrm{B}} 802.3^{\mathrm{a}}$ \\
24 & ${ }^{\mathrm{A}} 0.00^{\mathrm{f}}$ & ${ }^{\mathrm{A}} 60.00^{\mathrm{e}}$ & ${ }^{\mathrm{A}} 83.00^{\mathrm{d}}$ & ${ }^{\mathrm{A}} 111.75^{\mathrm{c}}$ & ${ }^{\mathrm{A}} 353.75^{\mathrm{b}}$ & ${ }^{\mathrm{A}} 890.9^{\mathrm{a}}$ \\
48 & ${ }^{\mathrm{A}} 0.00^{\mathrm{f}}$ & ${ }^{\mathrm{B}} 58.00^{\mathrm{e}}$ & ${ }^{\mathrm{B}} 77.50^{\mathrm{d}}$ & ${ }^{\mathrm{B}} 98.75^{\mathrm{c}}$ & ${ }^{\mathrm{C}} 331.75^{\mathrm{b}}$ & ${ }^{\mathrm{C}} 718.0^{\mathrm{a}}$ \\
\hline 6 & Non- calcareous soil & & \\
\hline 6 & ${ }^{\mathrm{A}} 0.00^{\mathrm{e}}$ & ${ }^{\mathrm{D}} 60.00^{\mathrm{d}}$ & ${ }^{\mathrm{C}} 64.00^{\mathrm{cd}}$ & ${ }^{\mathrm{C}} 75.75^{\mathrm{c}}$ & ${ }^{\mathrm{C}} 308.75^{\mathrm{b}}$ & ${ }^{\mathrm{D}} 492.5^{\mathrm{a}}$ \\
24 & ${ }^{\mathrm{A}} 0.00^{\mathrm{f}}$ & ${ }^{\mathrm{C}} 60.73^{\mathrm{e}}$ & ${ }^{\mathrm{B}} 75.75^{\mathrm{d}}$ & ${ }^{\mathrm{B}} 87.25^{\mathrm{c}}$ & ${ }^{\mathrm{B}} 330.50^{\mathrm{b}}$ & ${ }^{\mathrm{C}} 631.3^{\mathrm{a}}$ \\
48 & ${ }^{\mathrm{A}} 0.00^{\mathrm{f}}$ & ${ }^{\mathrm{A}} 62.00^{\mathrm{e}}$ & ${ }^{\mathrm{A}} 88.00^{\mathrm{d}}$ & ${ }^{\mathrm{A}} 105.5^{\mathrm{c}}$ & ${ }^{\mathrm{AB}} 337.09^{\mathrm{b}}$ & ${ }^{\mathrm{A}} 875.5^{\mathrm{a}}$ \\
\hline
\end{tabular}

Values having different letters in a column indicate the significant differences ( $p=0.05)$; small letters for differences between the solution $P$ concentrations and capital letters for between the equilibrium times.

\section{Effects of equilibrium time on P sorption}

Phosphorus sorption was also significantly influenced by equilibrium time up to 24 hour. Phosphorus sorption increased with increasing equilibrium time (except 48 hour) in every case and the maximum sorption $\left(891 \mu \mathrm{g} \mathrm{g}^{-1}\right)$ was observed after 24 hour equilibrium time at $50 \mu \mathrm{g} \mathrm{ml}^{-1} \mathrm{P}$ solution in calcareous soil (Table 2) whereas it was $876 \mu \mathrm{g} \mathrm{g}^{-1}$ in non-calcareous soil. The formation of Ca-P mineral phases was increased with reaction time which results in enhancement of $\mathrm{P}$ sorption and decrease 
in available P content. Rajput et al. (2014) reported that during the initial 2 days most of the added $\mathrm{P}$ was sorbed (40-84\%) which indicates the percentage of $\mathrm{P}$ retention increased with time period. In our experiment, it was noticed that $\mathrm{P}$ sorption was increased with equilibrium time up to 24 hours and it was decreased after 48 hours at every rate of applied $\mathrm{P}$ concentration. This decreased amount of $\mathrm{P}$ retention might be due to desorption of $\mathrm{P}$ from the adsorbed sites. The fact is that applied $\mathrm{P}$ is not irreversibly fixed in unavailable forms in soils and sorbed $\mathrm{P}$ in soil is de-sorbable which is a major process influencing the long-term availability of $\mathrm{P}$ in soils (Said and Dakermanji, 1993). Saleh et al. (2015) recognized that after 48-hours of adsorption reaction, about $28 \%$ of tested soils showed low affinity toward P retention by soil colloids. Different experimental results also found that desorption rate and equilibrium time were related to sorption rate (Egwu and Hoseini, 2017; Heidari et al., 2017).

In this experiment, it was also observed that, the amount of $\mathrm{P}$ desorption increased with the amount of $\mathrm{P}$ sorbed which was similar with the findings of Said and Dakermanji (1993). So, the percentage of the total sorbed $\mathrm{P}$ that was desorbable was a function of equilibrium time and some factors like nature of its fixation, $\mathrm{P}$ sorption capacity soil, amount of $\mathrm{P}$ sorbed etc. It was also estimated that the rates of $\mathrm{P}$ sorption by soils were initially fast and then slowed down gradually for a long time without any evidence of ending (Kanwar and Grewal, 1971; Zhou and Li, 2001; Rajput et al., 2014).

\section{The Langmuir adsorption model}

Adsorption isotherm is an important tool to study the sorption behavior of soils. It also helps to understand the involved processes and summarize many aspects of soil$\mathrm{P}$ interactions by different parameters. A number of models have been developed to quantify the sorption characteristics, among them the most commonly used sorption model which is a favorable method to explain the $\mathrm{P}$ sorption in most soils, is Langmuir adsorption model (Langmuir, 1918). The results were tested for and observed the best fit to Langmuir model. The closeness of fit of the experimental adsorption data to the Langmuir adsorption model for both the soils are shown in Figures 1 and 2. Besides, the correlation coefficient ( $\mathrm{r}$ ) between $\mathrm{C} / \mathrm{X}$ and $\mathrm{C}$, adsorption maximum (b) and bonding energy (k) for both the soils are shown in Table 3. 
Table 3. Correlation between $\mathrm{C} / \mathrm{X}$ and $\mathrm{C}$, and Langmuir coefficients for calcareous and non-calcareous soils

\begin{tabular}{cccc}
\hline \multicolumn{4}{c}{ Calcareous soil } \\
\hline Equilibrium time (hour) & $\mathrm{b}\left(\mu \mathrm{g} \mathrm{g}^{-1}\right)$ & $\mathrm{k}\left(\mu \mathrm{g} \mathrm{g}^{-1}\right)$ & $\mathrm{r}$ \\
\hline 6 & 862.1 & 0.047 & 0.316 \\
12 & 857.6 & 0.056 & 0.249 \\
24 & 932.8 & 0.086 & 0.326 \\
48 & 921.7 & 0.065 & 0.398 \\
\hline \multicolumn{4}{l}{ Non- calcareous soil } \\
\hline 6 & 617.3 & 0.069 & 0.519 \\
24 & 766.9 & 0.072 & 0.433 \\
48 & 803.9 & 0.102 & 0.359 \\
\hline
\end{tabular}
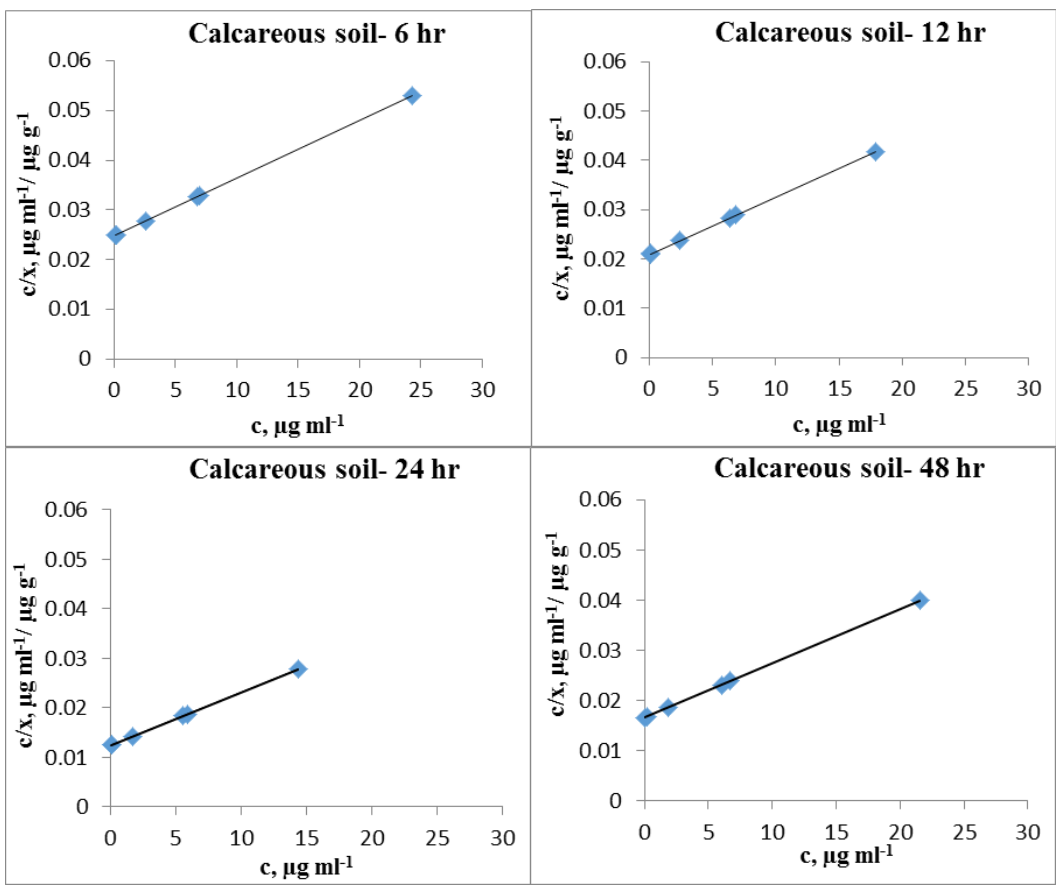

Figure 1. Langmuir adsorption plots for calcareous soil at different time duration 


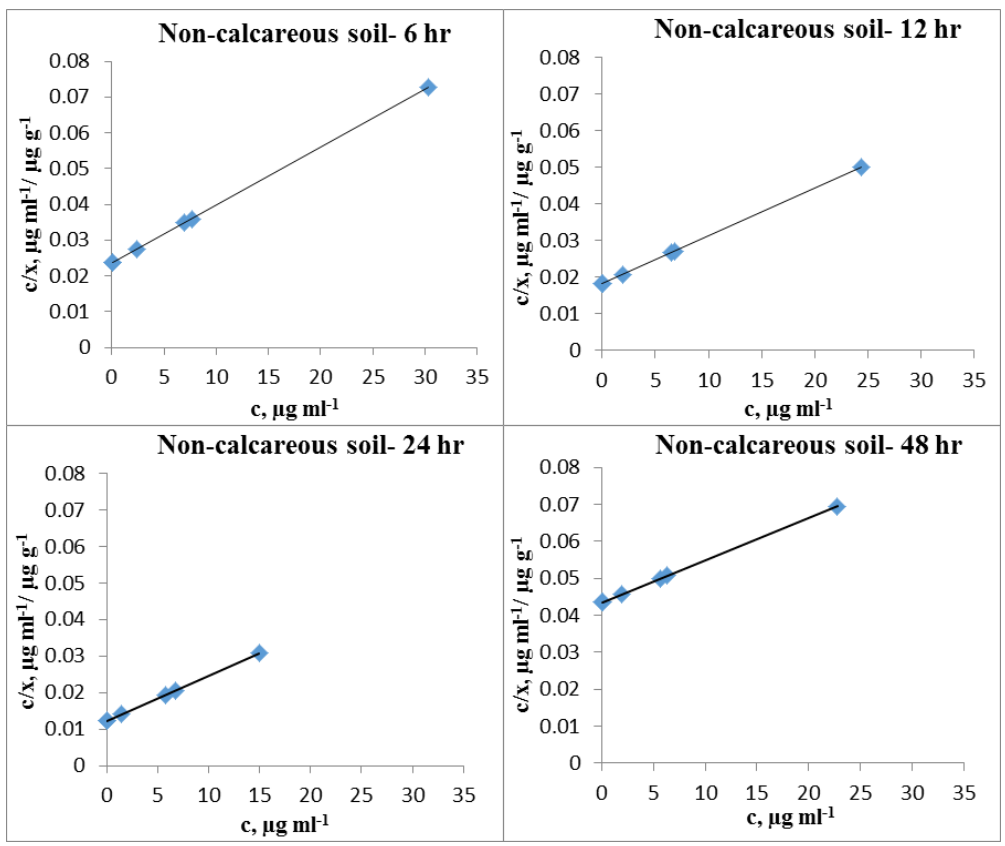

Figure 2. Langmuir adsorption plots for non-calcareous soil at different time durations

\section{CONCLUSION}

The study was done to compare the $\mathrm{P}$ sorption in two representative soils (calcareous and non-calcareous) with equilibrium time and solution $\mathrm{P}$ concentration. Results revealed that the $\mathrm{P}$ sorption was greatly affected by both the solution $\mathrm{P}$ concentration and equilibrium time. Phosphorus sorption was significantly increased with increasing solution $\mathrm{P}$ concentration in both calcareous and non-calcareous soils. Maximum sorption was found for concentration of $50 \mu \mathrm{g} \mathrm{P} \mathrm{ml}{ }^{-1}$ in solution. Equilibrium time had also a significant effect on P sorption in both the soils. Sorption of $\mathrm{P}$ was increased with equilibrium time up to 24 hours then it was decreased after 48 hours. The decreased $\mathrm{P}$ after 48 hours indicated that the $\mathrm{P}$ was adsorbed to its maximum level within 24 hours and it might be desorbed from the adsorption sites. Between calcareous and non-calcareous soils, the maximum sorption was found for calcareous soil irrespective to solution $\mathrm{P}$ concentration and equilibrium time.

\section{REFERENCES}

Afsar, M.Z., Hoque, S. and Osman, K.T. (2012a). A comparison of the Langmuir, Freundlich and Temkin equations to describe phosphate sorption characteristics of some representative soils of Bangladesh. International Journal of Soil Science, 7(3): 91-99.

Afsar, M.Z., Hoque, S. and Osman, K.T. (2012b). Phosphate desorption characteristics of some representative soils of Bangladesh: effect of exchangeable anions, water molecules and solution to soil ratios. Open Journal of Soil Science, 2(03): 234-241. 
Ahemad, M., Zaidi, A., Khan, M.S. and Oves, M. (2009). Biological importance of phosphorus and phosphate solubilizing microorganisms-an overview. Phosphate solubilizing microbes for crop improvement. Nova, New York. p. 1-4.

Awasthi, K.S. and Pathak, A.N. (1971). Effect of mechanical soil fractions on phosphate fixation by some soils of Uttar Pradesh. Indian Journal of Agricultural Research, 5: $134-38$.

Brady, N.C. and Weil, R.R. (2002). The nature and properties of soils. $13^{\text {th }}$ edition. Pearson Education (Singapore) Private Limited, Indian Branch, Delhi.

Bubba, K.E., Arias, E.C.A. and Brix, H. (2003). Phosphorus adsorption maximum of sands for use as media in subsurface flow constructed reed beds as measured by the Langmuir isotherm. Water Research, 37: 3390-3400.

Chen, M. and Ma, L.Q. (2001). Taxonomic and geographic distribution of total phosphorus in Florida surface soils.Soil Science Society of America Journal, 65: 1539-1547.

Cordell, D., Drangert, J.O. and White, S. (2009). The story of phosphorus: Global food security and food for thought. Global Environmental Change, 19: 292-305.

Egwu, U. and Hoseini, Y. (2017). Modeling the movement of phosphorus in some selected agricultural soils in Nigeria. Desert, 22(1): 31-42.

Gee, G.W. and Bauder, J.W. (1986). Particle size analysis. p. 383-411. In A. Klute (ed.), Methods of soil analysis, Part-1, Physical and mineralogical methods. Agronomy monograph No.9 ( $2^{\text {nd }}$ Edition). American Society of Agronomy, Madison. Wisconsin.

Grant, C.A., Flaten, D.N., Tomasiewicz, D.J. and Sheppard, S.C. (2001). The importance of early season P nutrition.Canadian Journal of Plant Science, 81:211-224.

Heidari, S., Reyhanitabar, A. and Oustan, S. (2017). Kinetics of phosphorus desorption from calcareous soils using DGT technique. Geoderma, 305: 275-280.

Hopkins, B. and Ellsworth, J. (2005). Phosphorus availability with alkaline/calcareous soil.Proceedings of the western nutrient management conference. Salt Lake City, UT, 6:88-93.

Huq, S.M.I. and Alam, M.D. (ed.) (2005). A handbook on analysis of soil, plant and water.BACER-DU, University of Dhaka, Banglaesh.ISBN-984-32-1770-5.

Jalali, M. (2007). Phosphorus status and sorption characteristics of some calcareous soils of Hamadan, western Iran. Environmental Geology, 53(2): 365-374.

Joardar, J.C., Rashid, M.H. and Huq, S.M.I. (2005). Adsorption of arsenic (As) in soils and in their clay fraction. Dhaka University Journal of Biological Sciences, 14(1): 51-61.

Kaloi, G.M., Bhughio, N., Panhwar, R.N., Junejo, S., Mari, A.H. and Bhutto, M.A. (2011). Influence of incubation period on phosphate release in two soils of district Hyderabad. Journal of Animal and Plant Sciences, 21: 665-670.

Kanwar, J.S. and Grewal, J.S. (1971). Phosphorus fixation in Indian soils. Indian Council of Agricultural Research, New Delhi.

Karim, Z., Hussain, S.G. and Ahmed, M. (1990). Salinity problems and crop intensification in the coastal regions of Bangladesh. Bangladesh Agricultural Research Council. Soils publication, 3(3): 3-6. 
Langmuir, I. (1918). The adsorption of gases on plane surfaces of glass, mica and platinum. Journal of the American Chemical society, 40(9): 1361-1403.

Moslehuddin, A.Z.M., Laizoo, S. and Egashira, K. (1997). Fertility status of Bangladesh soils-A review. Journal Faculty of Agriculture Kyushu University, 41: 257-267.

Mullins, G.L. (2009). Phosphorus, agriculture and the environment. VCE Publications. p. 424-429.

Rajput, A., Panhwar, Q.A., Naher, U.A., Rajput, S., Hossain, E. and Shamshuddin, J. (2014). Influence of incubation period, temperature and different phosphate levels on phosphate adsorption in soil. American Journal of Agricultural and Biological Sciences, 9: 251-260.

Said, M.B. and Dakermanji, A. (1993). Phosphate adsorption and desorption by calcareous soils of Syria. Communications in Soil Science and Plant Analysis, 24(1-2): 197-210.

Saleh, M.A., El-Gamal, E.H., Kamh, M.A. and Saad, A.F. (2015). Adsorption characteristics of phosphorus on calcite, mg-calcite and calcareous soils: effect of dissolved organic carbon. Alexandria Journal of Agricultural Research, 60(3): 269-282.

Sharpley, A.N. and Beegle, D. (2001). Managing phosphorus for agriculture and the environment. The Pennsylvania State's College of Agricultural Science. USA.

Shuman, L.M. (1975). The effect of soil properties on zinc adsorption by soils. Soil Science Society of America, 39: 454-458.

Soil Survey Manual. (1993). Soil survey division staff, chapter 3. Soil conservation service. U.S. Department of Agriculture, Handbook-18.

Soil Survey Staff. (1951). Soil texture. In Soil survey manual, soil survey staff (ed). p. 205213. United States Department of Agriculture handbook no. 18, United States government printing office, Washington D.C.

Thompson, D. (2007). The national soil map and soil classification. National Soil Resources Institute: Information Paper.

Withers, P.J.A. and Jarvie, H.P. (2008). Delivery and cycling of phosphorus in rivers, A review. Science of the Total Environment. 400(1-3): 379-395.

Worstall, T. (2013). Mineral demands: A shortage of fertilizer resources? Nature, 493: 163163.

Yadav, L.K., Bhagat, R.K. and Jatav, G.K. (2017). A study on relationship between soil and P adsorption parameters. International Journal of Current Microbiology and Applied Science, 6(8): 2822-2826.

Zhou, M. and Li, Y. (2001). Phosphorus-sorption characteristics of calcareous soils and limestone from the southern Everglades and adjacent farmlands. Soil Science Society of America Journal, 65(5): 1404-1412. 